\title{
Liquid Biopsies in Head and Neck Cancer: Current State and Future Challenges
}

\author{
Lingyi Kong ${ }^{1}$ and Andrew C. Birkeland ${ }^{2, *}$ \\ 1 The First Clinical College of Tongji Medical College, Huazhong University of Science and Technology, \\ Wuhan 430030, China; u201712215@hust.edu.cn \\ 2 Department of Otolaryngology-Head and Neck Surgery, University of California, Davis, CA 95817, USA \\ * Correspondence: acbirkeland@ucdavis.edu
}

Citation: Kong, L.; Birkeland, A.C. Liquid Biopsies in Head and Neck Cancer: Current State and Future Challenges. Cancers 2021, 13, 1874. https://doi.org/10.3390/cancers 13081874

Academic Editor: Therese Becker

Received: 1 March 2021

Accepted: 7 April 2021

Published: 14 April 2021

Publisher's Note: MDPI stays neutral with regard to jurisdictional claims in published maps and institutional affiliations.

Copyright: (c) 2021 by the authors. Licensee MDPI, Basel, Switzerland. This article is an open access article distributed under the terms and conditions of the Creative Commons Attribution (CC BY) license (https:// creativecommons.org/licenses/by/ $4.0 /)$.
Simple Summary: This review covers the most recent and up-to-date literature on liquid biopsy techniques in head and neck cancer. Head and neck cancer remains a common, difficult to treat and deadly type of disease. Part of the challenge in treating head and neck cancer lies in identifying disease at its early stages, determining responses to treatment and managing any recurrent disease. Liquid biopsies are the sampling of body fluids to determine markers that can indicate the presence of cancer. These technologies have immense potential in helping improve treatment for head and neck cancers. In this review, we discuss the current state of liquid biopsies for head and neck cancer, as well as limitations and challenges the field must overcome to advance our research in this area.

Abstract: Head and neck cancers are the seventh most frequent malignancy worldwide, consisting of a heterogeneous group of cancers that develop in the oral cavity, pharynx, and larynx, with head and neck squamous cell carcinoma (HNSCC) being the most common pathology. Due to limitations with screening and physical examination, HNSCC often presents in advanced disease states and is thus associated with poor survival. In this setting, liquid biopsies, or obtaining patient bodily fluid samples for cancer diagnosis and prognosis, may play a dramatic role in optimizing care for HNSCC patients. In recent years, there have been dramatic advancements in investigations focused on optimizing and implementing liquid biopsies in general, and specifically for HNSCC patients. Moving forward, there remain significant challenges in liquid biopsy technological development, as well as opportunities for the development of HNSCC liquid biopsy clinical trials and treatment paradigms. In this review, we discuss the current state of liquid biopsy technologies via circulating tumor cells, circulating tumor DNA and exosomes, approaches in head and neck cancer, challenges to optimization and application of liquid biopsies for clinical study, and future prospects for this field of research as it applies to head and neck cancer.

Keywords: head and neck cancer; liquid biopsy; circulating tumor cells; circulating tumor DNA; exosomes; head and neck squamous cell carcinoma

\section{Introduction}

Head and neck cancer is the seventh most common cancer worldwide, with 890,000 new cases and 450,000 deaths in 2018 [1], representing 3\% of all cancers and slightly above 1.5\% of all cancer deaths in the United States [2]. Head and neck squamous cell carcinomas (HNSCC) are by far the most common form of head and neck cancer, arising from mucosal surfaces of the oral cavity, pharynx, and larynx. Head and neck squamous cell carcinomas have been historically found in older patients with heavy tobacco and alcohol use; recently, there has been a declining global trend in traditional HNSCC cases due to decreased use of tobacco [3,4], counterbalanced with increased cases of HPV-associated oropharyngeal cancer (primarily by HPV type 16) [4,5].

In the era of exome- and genome-wide sequencing, tumor molecular profiling has been important in better understanding the diagnosis, treatment and prognosis of HNSCC 
in clinical practice. Currently, analysis based on tissue biopsy or cytology samples is still the gold standard in diagnosis of HNSCC. However, tissue biopsy may involve invasive procedures, often in a general anesthetic surgical setting. Thus, there are limitations in tissue access and repeatability of tumor sampling with current biopsy techniques. As there are considerable benefits to repeated biopsies both spatially (to account for tumor heterogeneity) and temporally (to account for dynamic tumor evolution), new methodologies for cancer diagnosis and assessment are needed. Over the last decade, there has been increasing interest in using liquid biopsies to detect cancer-specific biomarkers in patients' body fluids [6,7]. Liquid biopsy has been reported to play roles in early malignancy detection in diverse tumor types $[8,9]$. As a rapid and noninvasive approach, liquid biopsies have emerged as an exciting investigational avenue to obtain information on cancer diagnosis, treatment response, and progression [10,11].

In general, liquid biopsy refers to analytes from various biological fluids, such as blood or other accessible fluids: ascites, pleural effusions, saliva, or urine. Most liquid biopsy-based diagnostic tests for solid malignancies are based on blood serum or plasma specimens [6,7]. In studies of HNSCC, saliva is an additional medium for detection of tumor biomarkers [12]. Currently, the most common analytes used for liquid biopsy include circulating tumor cells (CTCs), cell-free tumor DNA (ctDNA), proteins, metabolites, exosomes (EXOs), mRNA, and miRNAs. In this review, we will focus on the applications of CTCs, ctDNA, and EXOs in head and neck cancer diagnosis, response to therapy, and prognosis. Additionally, we will: (i) review the current state of literature using these biomarkers in head and neck cancer, (ii) summarize current technological challenges and (iii) provide an outlook on future prospects in this rapidly evolving field.

\section{Circulating Tumor Cells in Head and Neck Cancer}

\subsection{Characterization and Detection Techniques}

Circulating tumor cells (CTCs) represent transient cancer cells originating from a primary tumor or metastatic sites that have the capacity to enter the adjacent vasculature and disseminate to distant sites [13]. Notably, CTCs are extremely rare, with approximately $1-100 \mathrm{CTC} / \mathrm{mL}$ among billions of red blood cells [14], making it challenging to detect and capture CTCs from whole blood samples.

Different methods have been established to isolate CTCs, which can be broadly classified as either label-dependent (a positive selection of CTCs making use of specific markers expressed by tumor cells, such as epithelial cell adhesion molecules (EpCAM), cytokeratins (CKs) and integrins) [15] or label-independent (based on physical property differences such as size and density between CTCs and surrounding blood cells) [16]. Integrins, being cell surface receptors highly expressed in many different tumor types, have been an intriguing target for isolating CTCs. Some researchers have applied tumor cell specific ligands, such as LXY30 [15], targeting alpha 3 beta1 integrin, to enrich lung cancer CTCs from patient blood. Similarly, utilizing ligands targeting integrins (also highly expressed in HNSCCs) or other HNSCC cell surface ligands (e.g., Epidermal growth factor receptor which is frequently overexpressed in HNSCC) could increase the isolation and capture of rare CTCs. Biochemical-based schemes have been predominantly adopted for CTC isolation, with the CellSearch system being the only FDA-approved platform so far [17]. Nevertheless, selection bias exists, as CTCs undergoing epithelial-mesenchymal transition (EMT) reduce their expression of EpCAM and CKs, with EpCAM being particularly variable in HNSCC [18]. Conventional methods based on epithelial markers might not capture EMT-transformed CTCs and thus, might underestimate or fail to detect CTCs. To address this issue, negative selection targeting on blood cells for depletion rather than tumor cells for enrichment has been proposed, as CTCs do not express blood cell markers such as CD45 and CD235a [19]. Despite efforts to optimize CTC capture efficiency, satisfying outcomes in cell purity is yet to be achieved [20].

Recently, many new platforms have emerged to overcome the abovementioned challenges. Label-free inertial microfluidics approaches, for example, can avoid underesti- 
mation of CTC exhibiting downregulation of surface marker expression, and have been reported to be able to detect a larger CTC pool (3-133 CTC $/ \mathrm{mL}$ of blood) than what had been previously achieved by the CellSearch system [21]. Researchers have also developed a 2-step CTC isolation and purification method, integrating a negative selection-based CTC isolation scheme and a subsequent 8-day spheroid cell culture for the further purification of CTCs, thereby isolating CTCs with higher purity [22].

\subsection{Circulating Tumor Cells as Prognostic Biomarkers}

With advances in technologies of CTC isolation and enumeration, there is a growing amount of research focusing on the value and potential use of CTC counts in cancer prognosis and treatment response, many of which have investigated the relationship between CTC quantitative counts and survival outcomes (Table 1). In a prospective clinical follow-up study involving 48 patients with HNSCC, Jatana et al. measured CTC numbers by the negative depletion method and observed an improved disease-free survival with no CTCs present and a worse clinical outcome with $>25 \mathrm{CTCs} / \mathrm{mL}$ [23]. They reported a significant correlation between CTC presence and decreased disease-free survival (DFS) for the first time in a HNSCC population. However, in a large cohort study of 144 patients with locally advanced HNSCC, results suggested that the presence of CTCs was not predictive for DFS and overall survival (OS) in the cohort. Curiously, CTC detection trended with improved DFS and OS in patients with oropharyngeal carcinomas, while being a prognostic marker of worse DFS and OS in non-oropharyngeal HNSCC patients [24], suggesting CTCs (as currently detected) remain an imperfect prognostic liquid biomarker. 
Table 1. Key studies investigating circulating tumor cells (CTCs) as biomarkers in head and neck squamous cell carcinomas (HNSCCs).

\begin{tabular}{|c|c|c|c|c|c|c|}
\hline Population/Trial Design & Detection Methodology & $\begin{array}{l}\text { Primary } \\
\text { Outcome }\end{array}$ & Major Findings & Study Strengths & Study Limitations & References \\
\hline $\begin{array}{l}\text { HNSCC undergoing } \\
\text { definitive surgery }\end{array}$ & $\begin{array}{l}\text { Negative depletion } \\
\text { followed by positive } \\
\text { staining (CK) }\end{array}$ & Disease-free survival (DFS)1 & $\begin{array}{c}\text { Patients with no detectable } \\
\text { CTCs had } \\
\text { significantly higher DFS }\end{array}$ & $\begin{array}{l}\text { Patients treated homogenously } \\
\text { with surgery }\end{array}$ & $\begin{array}{l}\text { Single timepoint study, } \\
\text { drawn during surgery }\end{array}$ & [23] \\
\hline $\begin{array}{l}\text { Stage III-IV HNSCC after } \\
\text { definitive surgery, } \\
\text { undergoing adjuvant } \\
\text { (chemo)radiation (CRT) }\end{array}$ & Positive staining (EGFR) & $\begin{array}{l}\text { 1. DFS } \\
\text { 2. Overall survival (OS) }\end{array}$ & $\begin{array}{l}\text { 1. CTCs detectable in } 29 \% \text { of } \\
\text { patients } \\
\text { 2. Non-OPSCC HNSCC patients } \\
\text { with } \\
\text { detectable CTCs have worse } \\
\text { DFS and OS }\end{array}$ & $\begin{array}{l}\text { 1. Patients treated } \\
\text { homogeneously with surgery, } \\
\text { followed by adjuvant therapy } \\
\text { 2. Large cohort }(n=144)\end{array}$ & $\begin{array}{l}\text { 1. Relying on EGFR } \\
\text { positivity to define CTC } \\
\text { 2. Single timepoint study }\end{array}$ & [24] \\
\hline Treatment-naïve HNSCC & $\begin{array}{l}\text { ClearCell FX system } \\
\text { Negative depletion (CD45) } \\
\text { Positive staining (CK) }\end{array}$ & $\begin{array}{l}\text { Progression-free survival } \\
\text { (PFS) }\end{array}$ & $\begin{array}{c}\text { 1. CTCs detectable in } 47.8 \% \text { of } \\
\text { patients } \\
\text { 2. Patients with detectable CTCs } \\
\text { have worse PFS } \\
\text { 3. PD-L1 positive CTCs } \\
\text { associated with worse survival }\end{array}$ & $\begin{array}{l}\text { Analysis of multiple expression } \\
\text { markers (PD-L1, ALK, EGFR) }\end{array}$ & $\begin{array}{l}\text { 1. Small cohort }(n=23) \\
\text { 2. Single timepoint study } \\
\text { 3. Mixed study with various } \\
\text { stages, treatments }\end{array}$ & [25] \\
\hline $\begin{array}{l}\text { Advanced OSCC after } \\
\text { induction chemotherapy, prior } \\
\text { to definitive } \\
\text { treatment }\end{array}$ & Positive staining (EpCAM) & $\begin{array}{l}\text { 1. Recurrence-free survival } \\
\text { (RFS) } \\
\text { 2.OS }\end{array}$ & $\begin{array}{l}\text { 1. CTCs detectable in } 80 \% \text { of } \\
\text { patients } \\
\text { 2. Higher baseline CTC and } \\
\text { maximal CTC associated with } \\
\text { worse RFS and OS }\end{array}$ & $\begin{array}{l}\text { 1. Phase II trial with defined } \\
\text { induction chemotherapy } \\
\text { protocol } \\
\text { 2.Serial timepoints } \\
\text { 3. Homogeneous population of } \\
\text { OSCC undergoing treatment }\end{array}$ & $\begin{array}{l}\text { 1. Protocol not reflecting } \\
\text { general standard of care } \\
\text { 2. Smaller cohort }(n=40)\end{array}$ & [26] \\
\hline $\begin{array}{c}\text { HNSCC patients } \\
\text { undergoing definitive CRT }\end{array}$ & Negative depletion & $\begin{array}{l}\text { 1. PFS } \\
\text { 2. OS }\end{array}$ & $\begin{array}{l}\text { 1. CTC reduction associated } \\
\text { with response to } \\
\text { chemoradiation and improved } \\
\text { PFS and OS }\end{array}$ & Serial timepoints & $\begin{array}{l}\text { Cohort limited to } \\
\text { chemoradiation patients }\end{array}$ & [27] \\
\hline $\begin{array}{c}\text { Advanced HNSCC } \\
\text { undergoing definitive CRT }\end{array}$ & $\begin{array}{c}\text { Negative depletion (CD45) } \\
\text { Positive staining (CK, } \\
\text { EpCAM, EGFR) }\end{array}$ & Detecting metastases & $\begin{array}{c}\text { 1. CTCs detected in } 42 \% \text { of } \\
\text { patients } \\
\text { 2. N2b or higher stage } \\
\text { associated with higher CTCs }\end{array}$ & $\begin{array}{c}\text { 1. Robust protocol for CTC } \\
\text { delineation } \\
\text { 2. Serial timepoints }\end{array}$ & $\begin{array}{l}\text { 1. Small cohort }(n=26) \\
\text { 2. Cohort limited to } \\
\text { chemoradiation patients } \\
\text { 3. No survival analyses }\end{array}$ & [28] \\
\hline $\begin{array}{c}\text { Advanced HNSCC } \\
\text { undergoing induction } \\
\text { chemotherapy, followed by } \\
\text { definitive CRT }\end{array}$ & Positive staining (EpCAM) & $\begin{array}{l}\text { 1. PFS } \\
\text { 2. OS }\end{array}$ & $\begin{array}{l}\text { PD-L1 overexpression on CTC } \\
\text { associated with worse PFS and } \\
\text { OS }\end{array}$ & $\begin{array}{l}\text { 1. Large cohort }(n=113) \\
\text { 2. Investigation of PD-L1 as } \\
\text { biomarker }\end{array}$ & $\begin{array}{l}\text { Cohort limited to } \\
\text { chemoradiation patients }\end{array}$ & [29] \\
\hline
\end{tabular}


Studies have also begun to illustrate the possible application of CTCs in monitoring disease status by conducting serial measurements of CTC levels. Inhestern et al. assessed and analyzed CTC counts from blood samples of 40 patients with oral cavity SCC (OSCC) before, during, and after treatment [26]. Similarly, Wang et al. investigated CTC counts of 47 HNSCC patients throughout concurrent chemoradiotherapy [27]. Both studies concluded that changes in CTC levels were highly correlative with tumor response to treatment, with persistently high CTC levels corresponding with worse prognosis and treatment response and decreasing CTC levels correlating with improved response and outcomes.

Additionally, CTC count was reported to have a predictive value for regional metastasis in head and neck cancer. In a study that included 42 patients with locally advanced HNSCC, the detection of CTC was discovered to correlate with the nodal stage as well as regional metastasis [28]. Kulasinghe et al. demonstrated in a cohort of 60 head and neck cancer patients that the presence of CTC clusters was significantly associated with distant metastatic disease [25]. Despite these initial encouraging findings, further research is undoubtedly needed to determine the role of CTC as a biomarker for treatment response and tumor state in head and neck cancer.

\subsection{Circulating Tumor Cells as Immunotherapeutic Biomarkers}

Immunotherapy has become a promising approach for the management and treatment of numerous cancers, including HNSCC, due to the emergence of immune checkpoint inhibitors [30]. There is interest in investigation of the role of CTCs in modulating disease behavior apart from its promise as a prognostic biomarker. Programmed death 1 (PD1) checkpoint inhibitors may block the PD-1/PD-L1 immune checkpoint pathway on CTCs and activate the immune system to eliminate CTCs in circulation, thus potentially reducing the risk of metastasis and disease recurrence.

PD-L1 overexpression in CTCs was detected and used for treatment response monitoring in patients with OSCC [31]. Strati et al. demonstrated (for the first time) that assessment of CTCs overexpressing PD-L1 in liquid biopsies is feasible, with implications for monitoring patients on PD1 inhibitors-and with the potential to provide important prognostic information in a prospective cohort of locally advanced HNSCC patients. By using RT-qPCR, PD-L1 overexpression was found in 24 (25.5\%) of 94 patients at baseline, $8(23.5 \%)$ of 34 patients after nonsurgical treatment, including chemoradiation, and 12 $(22.2 \%)$ of 54 patients at the end of definitive treatment [29]. An application of CTCs in HNSCC was proposed such that patients with high baseline PD-L1 expression be given a monotherapy with a PD-1/PD-L1 inhibitor, and patients with low PD-L1 expression be selected for combination therapy [32]. PD-L1 overexpression at the end of treatment was also revealed as an important independent prognostic factor which correlated with shorter progression-free survival (PFS) and overall survival (OS) compared with PD-L1 negative counterparts [29]. Similarly, a study with an HNSCC cohort treated with nivolumab found that PD-L1-positive CTCs were significantly associated with worse outcomes [25]. Other immune-regulatory molecules in CTCs, including PD-L2 and CD47, were investigated as well. Researchers have suggested that expressions of these three immune-regulatory molecules were positively correlated to one another [33].

\section{Circulating Tumor DNA in Head and Neck Cancer}

\subsection{Characteristics and Detection Techniques}

Liquid biopsy techniques have also been focused on cancer-derived non-cellular components that circulate in the bloodstream. Most prominent in these studies have been circulating tumor DNA (ctDNA). Circulating tumor DNA refers to extracellular DNA (cell-free DNA) released into the bloodstream by the sloughing cancer cells, through both pathological and physiological mechanisms, including cellular apoptosis and necrosis from rapidly proliferating cancer cells [34]. cfDNA is present in noncancer states, originating from apoptotic and necrotic cells, which are then phagocytosed by macrophages and other scavenger cells, under normal circumstances. In cancerous states, ctDNA enters circulation 
in increased amounts when phagocytosis is exhausted or impaired within the tumor [35]. Thus, in patients with cancer, cfDNA is comprised of a combination of noncancer cell DNA from normal cells and ctDNA from cancer cells. Generally, ctDNA represents a small fraction of total cfDNA (usually $<1.0 \%$ ) but may vary from less than $0.1 \%$ to over $10 \%$ depending on tumor burden, cancer stage, cellular turnover, and response to therapy [36], thus making detection and quantification challenging via traditional sequencing and analysis approaches [37].

The advent of new digital technologies has helped address this challenge, as two major methods (targeted and untargeted ctDNA approaches) are being studied and optimized [6]. Targeted approaches include PCR-based technologies such as BEAMing (beads, emulsion, amplification, and magnetic) and droplet digital PCR (ddPCR), which can optimize samples with low DNA counts or concentration, e.g., ctDNA. Additionally, certain Next-generation sequencing based technologies are being utilized to help isolate and capture ctDNA, including TAm-Seq (tagged amplicon deep sequencing), CAPP-Seq (cancer personalized profiling by deep sequencing), Safe-Seq (safe sequencing system), and AmpliSeq [38,39], each with relative strengths in sensitivity and scalability [40]. Untargeted approaches include other types of NGS-based technologies, including whole genome sequencing (WGS) and whole exome sequencing (WES), which do not require any prior knowledge of molecular alteration but are comparatively less cost-effective [41].

Studies have shown that quantification of copy number aberrations (CNAs), human papillomavirus (HPV) DNA, and somatic mutations in low level ctDNA in plasma from HNSCC patients is technically feasible via TAm-Seq, AmpliSeq, ddPCR and WGS. Combined analyses contribute to a higher sensitivity, which is paramount to utility [42-45]. Despite current limitations, investigators are having success detecting and isolating minor amounts of ctDNA from body fluids, thus opening the gate to a variety of clinical applications [46]. As technological advances continue, greater sensitivity and specificity may allow for further enhanced clinical application.

\section{2. ctDNA as a Biomarker for Disease Staging and Detection}

The concept that ctDNA concentration is increased in patients with HNSCC - and correlates with disease severity - is foundational to considering ctDNA as a diagnostic and prognostic tool (Table 2). Mazurek et al. assessed total ctDNA levels in 200 patients with HNSCC, as compared to a noncancer control group. They found that the mean level of total ctDNA was higher in the HNSCC group, especially in oropharyngeal SCCs (OPSCCs), and correlated with nodal status [47]. Similarly, Bettegowda et al. evaluated the detection of ctDNA as a prognostic tool in 359 patients with 15 various cancer types, including HNSCC. By comparing patients with metastatic cancer versus nonmetastatic cancer patients, there was a clear trend with regards to metastatic stage of disease and increased ctDNA quantity [48]. Several feasibility studies have shown that in virallymediated cancers (e.g., in the head and neck, HPV-related oropharyngeal cancer, and Epstein-Barr virus-mediated nasopharyngeal cancer), circulating HPV and EBV DNA from either plasma or saliva is useful for diagnosing disease at an earlier stage $[44,49,50]$. This highlights the potential utility of tumor-specific DNA in liquid biopsy for pretreatment phases for head and neck cancer detection and staging, as well as in screening of atrisk populations. 
Table 2. Key studies investigating circulating tumor DNA (ctDNA) as biomarkers in HNSCC.

\begin{tabular}{|c|c|c|c|c|c|c|}
\hline $\begin{array}{c}\text { Population/Trial } \\
\text { Design }\end{array}$ & Detection Methodology & Primary Outcome & Major Findings & Study Strengths & Study Limitations & References \\
\hline $\begin{array}{l}\text { Asymptomatic population } \\
\text { screening }\end{array}$ & $\begin{array}{l}\text { RT-PCR for plasma EBV } \\
\text { ctDNA }\end{array}$ & $\begin{array}{l}\text { 1. Rate of EBV DNA } \\
\text { positivity } \\
\text { 2. Rate of NPC in } \\
\text { positive EBV DNA } \\
\text { patients } \\
\text { 3. Sensitivity, specificity } \\
\text { of EBV DNA for NPC }\end{array}$ & $\begin{array}{c}\text { 1. 5.5\% detectable EBV DNA } \\
\text { rate } \\
\text { 2. } 11 \% \text { confirmed NPC } \\
\text { among EBV DNA positive } \\
\text { patients } \\
\text { 3. } 97.1 \% \text { sensitivity, } 98.6 \% \\
\text { specificity for NPC }\end{array}$ & $\begin{array}{l}\text { 1. Robust population study } \\
(n>20,000) \text { of endemic } \\
\text { population for NPC } \\
\text { 2. Demonstration of utility } \\
\text { of EBV DNA as a screening } \\
\text { test }\end{array}$ & $\begin{array}{l}\text { 1. False positive rates for } \\
\text { EBV DNA } \\
\text { 2. Challenges to apply to } \\
\text { non-endemic } \\
\text { populations }\end{array}$ & {$[50]$} \\
\hline $\begin{array}{l}\text { HNSCC before definitive or } \\
\text { salvage therapy }\end{array}$ & $\begin{array}{c}\text { PCR (HPV, TP53, } \\
\text { PIK3CKA, CDKN2A, } \\
\text { FBXW7, HRAS, NRAS } \\
\text { mutations) for plasma } \\
\text { and/or saliva ctDNA }\end{array}$ & $\begin{array}{l}\text { 1. Rate of ctDNA } \\
\text { detection in saliva } \\
\text { 2. Rate of ctDNA } \\
\text { detection in plasma }\end{array}$ & $\begin{array}{c}\text { 1. } 96 \% \text { ctDNA detection rate } \\
\text { when both plasma and } \\
\text { saliva tested } \\
\text { 2. } 100 \% \text { saliva ctDNA } \\
\text { identified in OSCC patients }\end{array}$ & $\begin{array}{l}\text { 1. Demonstration of ability } \\
\text { to identify salivary ctDNA } \\
\text { 2. High detection rates } \\
\text { demonstrated } \\
\text { 3. Demonstration of } \\
\text { detection of non-virally } \\
\text { mediated HNSCC }\end{array}$ & $\begin{array}{l}\text { 1. Hetergeneous } \\
\text { population of HNSCC } \\
\text { patients } \\
\text { 2. Not all patients } \\
\text { obtained saliva and } \\
\text { blood testing } \\
\text { 3. No survival analyses }\end{array}$ & {$[44]$} \\
\hline $\begin{array}{l}\text { OPSCC before and after } \\
\text { definitive therapy }\end{array}$ & $\begin{array}{l}\text { RT-PCR for plasma and } \\
\text { saliva HPV ctDNA }\end{array}$ & $\begin{array}{l}\text { 1. Negative predictive } \\
\text { value (NPV), positive } \\
\text { predictive value (PPV), } \\
\text { sensitivity, specificity of } \\
\text { HPV ctDNA for tumor } \\
\text { detection }\end{array}$ & $\begin{array}{l}\text { 1. Sensitivity } 76 \% \\
\text { 2. Specificity } 100 \% \\
\text { 3. NPV } 42 \% \\
\text { 4. PPV } 100 \%\end{array}$ & $\begin{array}{l}\text { 1. Serial timepoints } \\
\text { 2. Demonstration of } \\
\text { post-treatment ctDNA } \\
\text { positivity correlation with } \\
\text { worse survival }\end{array}$ & $\begin{array}{l}\text { 1. Protocol limited to } \\
\text { HPV-related HNSCC } \\
\text { 2. Poor NPV }\end{array}$ & [49] \\
\hline $\begin{array}{l}\text { HNSCC before and after } \\
\text { definitive therapy }\end{array}$ & $\begin{array}{c}\text { Next-generation } \\
\text { sequencing of plasma } \\
\text { ctDNA to compare to } \\
\text { identified primary tumor } \\
\text { DNA mutations }\end{array}$ & $\begin{array}{c}\text { Baseline ctDNA } \\
\text { mutation rates } \\
\text { correlating with primary } \\
\text { tumor }\end{array}$ & $\begin{array}{l}75 \% \text { plasma ctDNA } \\
\text { mutation rate }\end{array}$ & $\begin{array}{c}\text { Demonstration of utility of } \\
\text { mutational profiling with } \\
\text { primary tumor }\end{array}$ & $\begin{array}{l}\text { 1. Small cohort }(n=8) \\
\text { 2. No evidence of } \\
\text { correlation with ctDNA } \\
\text { positivity and recurrence }\end{array}$ & [51] \\
\hline $\begin{array}{c}\text { p16 positive OPSCC after } \\
\text { definitive CRT }\end{array}$ & ddPCR for HPV ctDNA & $\begin{array}{l}\text { NPV, PPV of HPV } \\
\text { ctDNA for cancer } \\
\text { surveillance }\end{array}$ & $\begin{array}{l}\text { 1. NPV } 100 \% \\
\text { 2. PPV } 94 \%\end{array}$ & $\begin{array}{l}\text { 1. Large cohort }(n=115) \\
\text { 2. Serial timepoints } \\
\text { 3. Demonstration of utility } \\
\text { of HPV DNA as a } \\
\text { surveillance test }\end{array}$ & $\begin{array}{l}\text { 1. Protocol limited to } \\
\text { HPV-related HNSCC }\end{array}$ & {$[52]$} \\
\hline
\end{tabular}




\section{3. ctDNA as a Biomarker for Post-Treatment Surveillance}

In the posttreatment setting, ctDNA can be used to assess residual disease and stratify patients at variable risk of recurrence following curative-intent therapy. Monitoring disease by ctDNA has increasingly been investigated in a number of malignancies, including breast and colorectal cancers $[53,54]$. In studies by Wang et al. and Ahn et al., HPV ctDNA from posttreatment HNSCC patients were also analyzed with promising results, providing the possibility of predicting disease recurrence using ctDNA [44,49]. In another study, Hamana et al. compared preoperative and postoperative levels of ctDNA in 64 patients with OPSCC. The number of patients with tumor-specific ctDNA dropped from $40 \%(28 / 64)$ to $20 \%(13 / 64)$ after treatment; moreover, among the 28 patients with measurable ctDNA preoperatively, those with no detectable ctDNA postoperatively had no disease recurrence, whereas 4 patients with postoperative detectable ctDNA subsequently developed distant metastases [55]. Egyud et al. studied the utility of ctDNA as a diagnostic tool for recurrence in 8 HNSCC patients. Their findings showed that two of four patients with recurrence had detectable plasma ctDNA prior to clinical manifestation [51].

Longitudinal monitoring of ctDNA may allow for repeated quick, noninvasive means to assay disease status at multiple timepoints [56]. A recent prospective clinical trial with 115 HPV-positive OPSCC patients measured longitudinal HPV ctDNA levels. Kinetic data measured during curative-intent chemoradiotherapy for a median time of 23 months demonstrated that all patients with recurrence had at least two consecutive abnormal plasma HPV ctDNA levels. Furthermore, of the 87 patients with undetectable HPV ctDNA after completion of chemoradiation, none had recurrences, thus showing high sensitivity and specificity for HPV ctDNA in identifying recurrent HPV-associated oropharyngeal HNSCC [52]. ctDNA has also been investigated as a tool to augment clinical decisionmaking in determining radiologic presence of disease. In a study by Rutkowski et al., patients with incomplete radiographic response and elevated HPV ctDNA levels were demonstrated by PET-CT to have recurrences, suggesting that more recurrent diseases may be discovered by combining ctDNA with radiographic examination, as opposed to radiographic imaging alone [57]. ctDNA levels were also compared with metabolic response (represented by PET-CT), and their predictive values for assessing treatment response were similar [58]. Thus, the ability to assess treatment response in HNSCC may be enhanced by combining ctDNA data from liquid biopsy with standard imaging results.

\section{Exosomes in Head and Neck Cancer}

\subsection{Characterization and Detection Techniques}

Exosomes (EXOs) are defined as a subset of extracellular vesicles (EVs) within a specific size (30-150 nm), released by cells, and detectable in most bodily fluids (e.g., saliva and blood) $[59,60]$. EV populations are membrane-bound vesicles consisting of various types of small vesicles. These include microvesicles and EXOs, which are distinguished by their biogenesis process and biophysical properties [61]. EXOs have a lipid bilayer structure containing proteins, miRNA, mRNA, and DNA that allows for intercellular communication. The lipid bilayer also contributes to the tumor microenvironment and immune response of HNSCC $[59,62]$. Excitingly, EXOs have recently been introduced as potential candidates for liquid biomarkers in cancer in general, and in HNSCC in particular.

Multiple methods have been developed for EXO isolation, based on either biophysical properties (e.g., size, solubility, and density) or immune affinity [63]. Ultracentrifugation and precipitation, for example, are common protocols, based on sedimentation velocity and solubility of particles, respectively. They yield a high volume of EXOs, but are timeconsuming and challenged by contamination and purity. Immunoaffinity capture methods select and isolates EXOs by recognizing specific surface antigens. They are less commonly used, owing to their relatively limited sample capacity, low yields, and high cost [46]. Clinical applications require a feasible and fast technique that can harvest EXOs with high purity and output. Therefore, researchers have established new platforms, including minisize exclusion chromatography (mini-SEC), to further enable reproducible isolation [64]. 


\subsection{EXOs as a Biomarker for Disease Staging and Detection}

Exosomes have had significant recent investigations into their utility as a biomarker representing disease state in HNSCC (Table 3). Studies demonstrating EXO expression patterns and functions regulating the tumor microenvironment [65] — and EXO concentration correlating with disease activity and tumor stage-are laying down the foundation for further investigations concerning head and neck cancer [66].

Table 3. Key studies investigating exosomes (EXOs) as biomarkers in HNSCC.

\begin{tabular}{|c|c|c|c|c|c|c|}
\hline $\begin{array}{c}\text { Population/Trial } \\
\text { Design }\end{array}$ & $\begin{array}{c}\text { Detection } \\
\text { Methodology }\end{array}$ & Primary Outcome & Major Findings & Study Strengths & Study Limitations & References \\
\hline HNSCC & $\begin{array}{l}\text { Size exclusion } \\
\text { chromatography, } \\
\text { CD63 staining }\end{array}$ & $\begin{array}{l}\text { 1. EXO PD-L1 levels } \\
\text { 2. Correlation of } \\
\text { EXO PD-L1 levels } \\
\text { with } \\
\text { clinicopathologic } \\
\text { disease }\end{array}$ & $\begin{array}{l}\text { High EXO PD-L1 } \\
\text { correlated with } \\
\text { advanced and } \\
\text { active disease }\end{array}$ & $\begin{array}{l}\text { Validation of } \\
\text { ability to test EXO } \\
\text { for marker } \\
\text { expression }\end{array}$ & $\begin{array}{l}\text { 1. Heterogeneous } \\
\text { HNSCC population } \\
\text { 2. Small } \\
\text { subpopulations, } \\
\text { correlations } \\
\text { preliminary }\end{array}$ & [67] \\
\hline $\begin{array}{c}\text { Laryngeal SCC } \\
\text { (LSCC) }\end{array}$ & CD63 staining & $\begin{array}{l}\text { 1. Correlation of } \\
\text { EXO miR-21 and } \\
\text { HOTAIR levels } \\
\text { with LSCC }\end{array}$ & $\begin{array}{l}\text { High EXO miR-21 } \\
\text { and HOTAIR } \\
\text { expression } \\
\text { correlated with } \\
\text { LSCC }\end{array}$ & $\begin{array}{c}\text { Validation of EXO } \\
\text { to differentiate } \\
\text { benign and } \\
\text { malignant } \\
\text { processes }\end{array}$ & $\begin{array}{l}\text { 1. Limited to LSCC } \\
\text { cohort } \\
\text { 2. No prognostic or } \\
\text { survival analyses }\end{array}$ & [68] \\
\hline $\begin{array}{l}\text { HNSCC before } \\
\text { and after } \\
\text { photodynamic } \\
\text { therapy }\end{array}$ & $\begin{array}{l}\text { Size exclusion } \\
\text { chromatography, } \\
\text { CD63 staining }\end{array}$ & $\begin{array}{l}\text { EXO E-Cadherin, } \\
\text { N-Cadherin and } \\
\text { TGF- } \beta 1 \text { levels }\end{array}$ & $\begin{array}{l}\text { Pre-treatment } \\
\text { EXO levels } \\
\text { enriched in } \\
\text { N-Cadherin and } \\
\text { TGF- } \beta 1\end{array}$ & $\begin{array}{l}\text { Investigation of } \\
\text { EXO cargo as } \\
\text { markers for } \\
\text { epithelial- } \\
\text { mesenchymal } \\
\text { transition }\end{array}$ & $\begin{array}{l}\text { 1. Small cohort }(n=9) \\
\text { 2. Non-standard of } \\
\text { care treatment } \\
\text { 3. Preliminary data }\end{array}$ & [69] \\
\hline $\begin{array}{c}\text { HNSCC } \\
\text { undergoing CRT } \\
\text { with } \\
\text { ipilimumab }\end{array}$ & $\begin{array}{l}\text { Size exclusion } \\
\text { chromatography, } \\
\text { CD63 staining }\end{array}$ & $\begin{array}{l}\text { 1. DFS } \\
\text { 2. EXO changes } \\
\text { during therapy }\end{array}$ & $\begin{array}{l}\text { Total EXO levels, } \\
\text { CD3 + CTLA4_ } \\
\text { EXOs decreased } \\
\text { after } \\
\text { ipilimumab }\end{array}$ & $\begin{array}{l}\text { 1. Phase I clinical } \\
\text { trial setting } \\
\text { 2. Serial } \\
\text { timepoints }\end{array}$ & $\begin{array}{l}\text { 1. Small cohort } \\
\quad(n=18) \\
\text { 2. Clinical trial } \\
\text { treatment population }\end{array}$ & {$[70]$} \\
\hline
\end{tabular}

Immune checkpoint antibody blockade of the PD1/PD-L1 pathway (blocking cancer cell suppression of functional $\mathrm{T}$ cells, allowing for $\mathrm{T}$ cell mediated antitumor recognition and response) is a recent advance in treatment for advanced, recurrent, and metastatic HNSCC [71]. Notably, EXOs can carry PD-L1, with implications on tumor microenvironment modulation and disease progression. Theodoraki et al. isolated EXOs from plasma of 40 patients with HNSCC and tested soluble PD-L1 by ELISA, finding that EXOs carried biologically active PD-L1. Exosome-bound PD-L1 correlated with tumor stage and lymph node status. This fundamental research suggested that circulating PD-L1 expression on EXOs can be used as a biomarker, as the levels of PD-L1 carried by EXOs were associated with disease progression in HNSCC patients [67].

MicroRNAs (miRNA) in blood and saliva have been noted to be concentrated in EXOs, with the ability to mediate cellular translational suppression, mRNA degradation and transcriptional regulation [72]. Langevin et al. isolated EXOs from four patients with HNSCC and compared the transcript levels of miRNAs in EXOs from noncancer patients and control cells. Their results showed that some EXO miRNA (including miR486-5p, miR-486-3p, and miR-10b-5p) — secreted solely by cancer cells in culture-were substantially elevated, suggesting that specific EXO miRNAs may be promising biomarkers in HNSCC [73]. Other studies focusing on miR-21 showed that the EXO miR-21 levels correlated with tumor stage and lymph node metastasis in oral, laryngeal, and esophageal SCC patients $[68,74,75]$. These studies emphasized the clinical impact of EXO miR-21 as a valuable biomarker for HNSCC progression. 


\subsection{EXOs as a Biomarker for Post-Treatment Surveillance}

Researchers also have been exploring the potential use of EXOs in the posttreatment surveillance phase for HNSCC. Theodoraki et al. detected plasma EXOs and tested their levels of E-Cadherin, N-Cadherin and TGF- $\beta 1$ by flow cytometry. EXOs obtained pretreatment with photodynamic therapy had a mesenchymal profile, enriched $\mathrm{N}$-Cadherin and TGF- $\beta 1$, and enhanced tumor proliferation, migration and invasion. EXOs collected after photodynamic therapy had an epithelial profile, carried E-cadherin, and inhibited proliferation, migration and invasion, suggesting EXO composition and their molecular cargo may serve a role in monitoring a patient's response to therapy [69]. In another study, 18 HNSCC patients receiving a combination of cetuximab, ipilimumab, and radiation therapy were serially monitored for tumor-associated EXOs and T cell-derived EXOs. Theodoraki et al. compared the molecular cargo of EXOs between patients who developed recurrent disease and those who remained disease free. Total EXO protein and total EXO ratios increased in disease-free patients, with total CD3+, CD3(-)PD-L1+ CD3+ 15s+ (Treg-derived) EXOs elevated from the baseline levels. These levels decreased in recurrent patients, supporting the potential role of EXOs as biomarkers for posttreatment surveillance and early detection of recurrence [70].

\section{Other Liquid Biomarkers in Head and Neck Cancer}

\subsection{RNA as a Liquid Biomarker in Head and Neck Cancer}

As noted above, miRNA shows promise as a liquid biomarker in head and neck cancer. Meanwhile, many studies investigating miRNA have focused on it as cargo within EXOs (as noted above). There are additional studies looking at plasma free miRNA, mRNA and lncRNA as liquid biomarkers in cancers, including HNSCC [76]. For instance, Lu et al. [77] demonstrated (with high sensitivity and specificity) that there was significantly higher expression of plasma miR-196a and mi-196b in patients with precancerous and cancerous oral cavity lesions compared to normal controls. In addition, Liu et el. reported a significant elevation in plasma miR-31 from OSCC patients, as well as a significant reduction after tumor resection-suggesting the feasibility of applying miRNAs for diagnostic uses [78]. In a similar fashion, Mayda et al. [79] investigated GAS5 lncRNA plasma levels in 41 patients with head and neck cancer, demonstrating that persistently elevated levels of this IncRNA were associated with persistent disease, with reasonable sensitivity and specificity. Combined, these data - while preliminary-are encouraging for further investigation of RNA as liquid biomarkers in head and neck cancer, whether associated with EXOs or as free plasma biomarkers.

\subsection{Metabolites as Liquid Biomarkers in Head and Neck Cancer}

Among liquid biomarkers for cancer, tumor metabolites have had a rich history of investigation. Several metabolomic studies have been undertaken recently to identify specific metabolites or metabolomic signatures and their association with HNSCC. For instance, Shahid et al. identified that (among 3326 evaluated metabolites) stearyl alcohol and sucrose were predictive markers between OSCC patients and noncancer patients [80]. There have been encouraging reports in other squamous cell carcinomas (esophageal, cervical) suggesting the potential utility of plasma lysophosphatidylcholines as sensitive and specific cancer liquid biomarkers [81,82]. Notably, there has been recent interest in studying metabolites as cargo in EXOs, as a potential further refinement as a cancer biomarker, including in preliminary cohorts of HNSCC patients [83]. As existing technology for detection of metabolites is fairly well-established and can be relatively cost-effective, this is a field of additional opportunity for refinement and clinical validation in head and neck cancer patients.

\section{Current Challenges and Future Directions}

In recent years, there has been tremendous advancement in the field of liquid biopsy for cancer in general, and head and neck cancer in particular. Critically, the development 
and refinement of isolation techniques for the major liquid biopsy targets (CTCs, ctDNA, EXOs; Table 4) have paved the way for preliminary studies investigating their utility in clinical scenarios. Nevertheless, there remain significant hurdles to overcome to increase the implementation and utility of liquid biomarkers in clinical care in HNSCC.

Table 4. Current strengths and limitations of major liquid biopsy targets.

\begin{tabular}{|c|c|c|c|}
\hline & CTC & ctDNA & EXO \\
\hline Detection Principles & $\begin{array}{l}\text { 1. Label-dependent methods } \\
\text { 2. Label-independent } \\
\text { methods }\end{array}$ & $\begin{array}{l}\text { 1. Targeted approaches } \\
\text { 2. Untargeted approaches }\end{array}$ & $\begin{array}{l}\text { 1. Immune affinity based } \\
\text { methods } \\
\text { 2. Biophysical property-based } \\
\text { approaches }\end{array}$ \\
\hline Biofluid Concentration & Very Low & Variable/Moderate & High \\
\hline Detection in Biofluids & Blood & Blood, saliva & Blood, saliva, urine, sweat \\
\hline Sensitivity & Low & Variable/Higher & Higher \\
\hline Specificity & Variable & Variable/Higher & Variable/Low \\
\hline $\begin{array}{l}\text { Clinical Readiness/Trials in } \\
\text { Head and Neck Cancer }\end{array}$ & $\begin{array}{l}\text { 1. Early phase data } \\
\text { 2. FDA-approved test in other } \\
\text { cancers }\end{array}$ & $\begin{array}{l}\text { Completed and ongoing trials } \\
\text { with EBV, HPV DNA }\end{array}$ & Not yet \\
\hline Other Characteristics & $\begin{array}{l}\text { +Can perform studies on } \\
\text { morphology and gene profile } \\
\text { +Immune checkpoint markers } \\
\text { on CTCs allowing } \\
\text { immunotherapeutic studies }\end{array}$ & $\begin{array}{l}+ \text { Short half-life } \\
+ \text { Able to detect genetic } \\
\text { mutations }\end{array}$ & $\begin{array}{c}\text { +Short half-life } \\
\text { +Can analyze variety of } \\
\text { molecular cargo (e.g., miRNA, } \\
\text { metabolites) } \\
\text { - Lack of standardization for } \\
\text { detection and isolation }\end{array}$ \\
\hline
\end{tabular}

Currently, all major liquid biopsy techniques face challenges; they have not yet achieved optimal sensitivity and specificity at a level acceptable for clinical use. Further refinement of platforms allowing for enhanced tumor-associated liquid biomarker capture will be critical to optimizing both sensitivity and specificity of assays, including immune affinity and label-dependent capture of CTCs and EXOs or ddPCR for ctDNA.

A critical challenge for all liquid biopsies is the ability to truly target and separate the cancer-associated biomarker from existing circulating cells, DNA and EXOs that are generated from noncancer tissues. As noted by the studies above, there is an opportunity for high specificity if the biomarker target is not endogenous or expressed by normal tissue, e.g., with HPV and EBV viral markers in appropriate virally-associated head and neck cancers. For nonvirally-associated HNSCCs, there are no ubiquitous mutations, surface markers, or other profiles that are completely specific to HNSCC. While studies, as noted above, have highlighted potential commonly altered profiles (e.g., mi-R21 for EXOs, TP53 or PIK3CA genetic mutations in CTCs, or ctDNA), these are far from universal. Future identification and validation of multiplex expression profiles (e.g., gene probes targeting ctDNA harboring any of a number of common mutations in HNSCC, targeting a combination of miRNA or tumor-associated surface markers on EXOs) may allow for increased sensitivity and specificity for isolating true cancer-associated liquid biomarkers.

While blood-based liquid biopsies have been the most common avenue of investigation, HNSCCs offer a unique opportunity for further refinement of salivary or oral rinse-based liquid biopsies, given that these cancers are of upper aerodigestive mucosal origin and can shed tumor cells, tumor DNA, and EXOs directly into oral and upper airway secretions. Indeed, further studies comparing the efficacy of salivary versus blood-based liquid biopsies (or combinations thereof) will be of great interest. Additionally, researchers are continuing to look for new liquid-based biomarkers other than the CTCs, ctDNA, and EXOs discussed above; for instance, in addition to RNA and metabolite biomarkers, tumor-educated platelets represent another promising liquid biopsy candidate [84]. 
As liquid biopsies in HNSCC increase in their sensitivity, specificity, and overall reliability, consideration of their incorporation into clinical trials will be of critical importance. As noted above, integrating these tests in order to augment current evaluations of disease status (as with radiologic response rates) may be a feasible initial design. With increased reliability, further treatment stratification based on liquid biomarker findings may be future solutions. Treatment algorithms can be in neoadjuvant settings (where currently archaic radiologic and clinical exams are our primary tumor response assessment methods), or in the adjuvant or surveillance setting (where it is currently challenging to detect any microscopic residual disease). Liquid biopsy-dependent trial design may be most achievable in EBV and HPV-related head and neck cancers, where the EBV and HPV DNA tests have been more vigorously investigated and validated. Indeed, clinical trials for nasopharyngeal cancer are already being launched that utilize EBV DNA for treatment stratification. The use of different high-throughput analytical platforms-as well as different biomarkers and capture systems-also highlights the need for interventional studies and large-scale clinical trials for validation and standardization [85-87].

\section{Conclusions}

Liquid biopsies-as a biomarker for disease detection, prognostication, and therapeutic intervention in head and neck cancer and cancer in general-are an alluring field of research. They hold great potential as a noninvasive, rapid, repeatable adjuvant tool for cancer detection and surveillance. As we rapidly approach an era with increased treatment stratification and personalization of cancer care, liquid biopsies may play a critical role in facilitating personalized management of head and neck cancer patients. Although there are current challenges_-including limited specificity, sensitivity and lack of standardizationtheir potential applications are rapidly expanding. In this review, we summarized the three most studied liquid biopsy biomarkers (CTCs, ctDNA and EXOs) for HNSCC. We examined the current state of their research, as well as challenges and opportunities for improvement for each technique. Undoubtedly, further studies and trials are imperative for liquid biopsies to be incorporated into standard of care clinical practice. Nevertheless, with dramatic recent advances in this field, the study of liquid biopsies in head and neck cancer will be of continuing great value and interest.

Author Contributions: Conceptualization, A.C.B. and L.K.; writing-original draft preparation, review and editing, L.K. and A.C.B. All authors have read and agreed to the published version of the manuscript.

Funding: Birkeland was funded by NIH K12CA138464.

Institutional Review Board Statement: Not applicable.

Informed Consent Statement: Not applicable.

Data Availability Statement: Not applicable.

Conflicts of Interest: The authors declare no conflict of interest.

\section{References}

1. Bray, F.; Ferlay, J.; Soerjomataram, I.; Siegel, R.L.; Torre, L.A.; Jemal, A. Global cancer statistics 2018: GLOBOCAN estimates of incidence and mortality worldwide for 36 cancers in 185 countries. CA Cancer J. Clin. 2018, 68, 394-424. [CrossRef] [PubMed]

2. Siegel, R.L.; Miller, K.D.M.; Jemal, A. Cancer statistics, 2018. CA Cancer J. Clin. 2018, 68, 7-30. [CrossRef]

3. Mourad, M.; Jetmore, T.; Jategaonkar, A.A.; Moubayed, S.; Moshier, E.; Urken, M.L. Epidemiological Trends of Head and Neck Cancer in the United States: A SEER Population Study. J. Oral Maxillofac. Surg. 2017, 75, 2562-2572. [CrossRef]

4. Fitzmaurice, C. Global Burden of Disease Cancer Collaboration Global, regional, and national cancer incidence, mortality, years of life lost, years lived with disability, and disability-adjusted life-years for 29 cancer groups, 2006 to 2016: A systematic analysis for the Global Burden of Disease study. J. Clin. Oncol. 2018, 36, 1568. [CrossRef]

5. Gillison, M.L.; Chaturvedi, A.K.; Anderson, W.F.; Fakhry, C. Epidemiology of Human Papillomavirus-Positive Head and Neck Squamous Cell Carcinoma. J. Clin. Oncol. 2015, 33, 3235-3242. [CrossRef] [PubMed]

6. Siravegna, G.; Marsoni, S.; Siena, S.; Bardelli, A. Integrating liquid biopsies into the management of cancer. Nat. Rev. Clin. Oncol. 2017, 14, 531-548. [CrossRef] 
7. Arantes, L.M.R.B.; De Carvalho, A.C.; Melendez, M.E.; Carvalho, A.L. Serum, plasma and saliva biomarkers for head and neck cancer. Expert Rev. Mol. Diagn. 2018, 18, 85-112. [CrossRef] [PubMed]

8. Cohen, J.D.; Javed, A.A.; Thoburn, C.; Wong, F.; Tie, J.; Gibbs, P.; Schmidt, C.M.; Yip-Schneider, M.T.; Allen, P.J.; Schattner, M.; et al. Combined circulating tumor DNA and protein biomarker-based liquid biopsy for the earlier detection of pancreatic cancers. Proc. Natl. Acad. Sci. USA 2017, 114, 10202-10207. [CrossRef] [PubMed]

9. Cohen, J.D.; Li, L.; Wang, Y.; Thoburn, C.; Afsari, B.; Danilova, L.; Douville, C.; Javed, A.A.; Wong, F.; Mattox, A.; et al. Detection and localization of surgically resectable cancers with a multi-analyte blood test. Science 2018, 359, 926-930. [CrossRef] [PubMed]

10. Russano, M.; Napolitano, A.; Ribelli, G.; Iuliani, M.; Simonetti, S.; Citarella, F.; Pantano, F.; Dell'Aquila, E.; Anesi, C.; Silvestris, N.; et al. Correction to: Liquid biopsy and tumor heterogeneity in metastatic solid tumors: The potentiality of blood samples. $J$. Exp. Clin. Cancer Res. 2020, 39, 120. [CrossRef] [PubMed]

11. Guthrie, G.J.; Charles, K.A.; Roxburgh, C.S.; Horgan, P.G.; McMillan, D.C.; Clarke, S.J. The systemic inflammation-based neutrophil-lymphocyte ratio: Experience in patients with cancer. Crit. Rev. Oncol. 2013, 88, 218-230. [CrossRef] [PubMed]

12. Shanmugam, A.; Hariharan, A.K.; Hasina, R.; Nair, J.R.; Katragadda, S.; Irusappan, S.; Ravichandran, A.; Veeramachaneni, V.; Bettadapura, R.; Bhati, M.; et al. Ultrasensitive detection of tumor-specific mutations in saliva of patients with oral cavity squamous cell carcinoma. Cancer 2021. [CrossRef] [PubMed]

13. Pantel, K.; Brakenhoff, R.H.; Brandt, B. Detection, clinical relevance and specific biological properties of disseminating tumour cells. Nat. Rev. Cancer 2008, 8, 329-340. [CrossRef] [PubMed]

14. Liu, H.E.; Triboulet, M.; Zia, A.; Vuppalapaty, M.; Kidess-Sigal, E.; Coller, J.; Natu, V.S.; Shokoohi, V.; Che, J.; Renier, C.; et al. Workflow optimization of whole genome amplification and targeted panel sequencing for CTC mutation detection. NPJ Genom. Med. 2017, 2, 34. [CrossRef]

15. Luo, A.; Zhou, X.; Shi, X.; Zhao, Y.; Men, Y.; Chang, X.; Chen, H.; Ding, F.; Li, Y.; Su, D.; et al. Exosome-derived miR-339-5p mediates radiosensitivity by targeting Cdc25A in locally advanced esophageal squamous cell carcinoma. Oncogene 2019, 38, 4990-5006. [CrossRef]

16. Alix-Panabières, C.; Pantel, K. Challenges in circulating tumour cell research. Nat. Rev. Cancer 2014, 14, 623-631. [CrossRef] [PubMed]

17. de Wit, S.; van Dalum, G.; Terstappen, L.W. Detection of circulating tumor cells. Scientifica 2014, 2014, 819362. [CrossRef]

18. Zeisberg, M.; Neilson, E.G. Biomarkers for epithelial-mesenchymal transitions. J. Clin. Investig. 2009, 119, 1429-1437. [CrossRef] [PubMed]

19. Lu, Y.; Liang, H.; Yu, T.; Xie, J.; Chen, S.; Dong, H.; Sinko, P.J.; Lian, S.; Xu, J.; Wang, J.; et al. Isolation and characterization of living circulating tumor cells in patients by immunomagnetic negative enrichment coupled with flow cytometry. Cancer 2015, 121, 3036-3045. [CrossRef]

20. Shen, Z.; Wu, A.; Chen, X. Current detection technologies for circulating tumor cells. Chem. Soc. Rev. 2017, 46, 2038-2056. [CrossRef]

21. Onidani, K.; Shoji, H.; Kakizaki, T.; Yoshimoto, S.; Okaya, S.; Miura, N.; Sekikawa, S.; Furuta, K.; Lim, C.T.; Shibahara, T.; et al. Monitoring of cancer patients via next-generation sequencing of patient-derived circulating tumor cells and tumor DNA. Cancer Sci. 2019, 110, 2590-2599. [CrossRef]

22. Liao, C.-J.; Hsieh, C.-H.; Hung, F.-C.; Wang, H.-M.; Chou, W.-P.; Wu, M.-H. The Integration of a Three-Dimensional Spheroid Cell Culture Operation in a Circulating Tumor Cell (CTC) Isolation and Purification Process: A Preliminary Study of the Clinical Significance and Prognostic Role of the CTCs Isolated from the Blood Samples of Head and Neck Cancer Patients. Cancers 2019, 11, 783. [CrossRef]

23. Jatana, K.R.; Balasubramanian, P.; Lang, J.C.; Yang, L.; Jatana, C.A.; White, E.; Agrawal, A.; Ozer, E.; Schuller, D.E.; Chalmers, J.J.; et al. Significance of circulating tumor cells in patients with squamous cell carcinoma of the head and neck: Initial results. Arch. Otolaryngol. Head Neck Surg. 2010, 136, 1274-1279. [CrossRef] [PubMed]

24. Tinhofer, I.; Konschak, R.; Stromberger, C.; Raguse, J.-D.; Dreyer, J.H.; Jöhrens, K.; Keilholz, U.; Budach, V. Detection of circulating tumor cells for prediction of recurrence after adjuvant chemoradiation in locally advanced squamous cell carcinoma of the head and neck. Ann. Oncol. 2014, 25, 2042-2047. [CrossRef] [PubMed]

25. Kulasinghe, A.; Kapeleris, J.; Kimberley, R.; Mattarollo, S.R.; Thompson, E.W.; Thiery, J.P.; O’Byrne, K.; Punyadeera, C. The prognostic significance of circulating tumor cells in head and neck and non-small-cell lung cancer. Cancer Med. 2018, 7, 5910-5919. [CrossRef] [PubMed]

26. Inhestern, J.; Oertel, K.; Stemmann, V.; Schmalenberg, H.; Dietz, A.; Rotter, N.; Veit, J.; Görner, M.; Sudhoff, H.; Junghanß, C.; et al. Prognostic Role of Circulating Tumor Cells during Induction Chemotherapy Followed by Curative Surgery Combined with Postoperative Radiotherapy in Patients with Locally Advanced Oral and Oropharyngeal Squamous Cell Cancer. PLoS ONE 2015, 10, e0132901. [CrossRef]

27. Wang, H.; Wu, M.; Chang, P.; Lin, H.; Liao, C.; Wu, S.; Hung, T.; Lin, C.; Chang, T.; Tzu-Tsen, Y.; et al. The change in circulating tumor cells before and during concurrent chemoradiotherapy is associated with survival in patients with locally advanced head and neck cancer. Head Neck 2019, 41, 2676-2687. [CrossRef]

28. Hristozova, T.; Konschak, R.; Stromberger, C.; Fusi, A.; Liu, Z.; Weichert, W.; Stenzinger, A.; Budach, V.; Keilholz, U.; Tinhofer, I. The presence of circulating tumor cells (CTCs) correlates with lymph node metastasis in nonresectable squamous cell carcinoma of the head and neck region (SCCHN). Ann. Oncol. 2011, 22, 1878-1885. [CrossRef] [PubMed] 
29. Strati, A.; Koutsodontis, G.; Papaxoinis, G.; Angelidis, I.; Zavridou, M.; Economopoulou, P.; Kotsantis, I.; Avgeris, M.; Mazel, M.; Perisanidis, C.; et al. Prognostic significance of PD-L1 expression on circulating tumor cells in patients with head and neck squamous cell carcinoma. Ann. Oncol. Off. J. Eur. Soc. Med. Oncol. 2017, 28, 1923-1933. [CrossRef]

30. Sharma, P.; Allison, J.P. The future of immune checkpoint therapy. Science 2015, 348, 56-61. [CrossRef]

31. Oliveira-Costa, J.P.; De Carvalho, A.F.; Da Silveira, D.G.G.; Amaya, P.; Wu, Y.; Park, K.-J.J.; Gigliola, M.P.; Lustberg, M.; Buim, M.E.C.; Ferreira, E.N.; et al. Gene expression patterns through oral squamous cell carcinoma development: PD-L1 expression in primary tumor and circulating tumor cells. Oncotarget 2015, 6, 20902-20920. [CrossRef]

32. Kulasinghe, A.; Kenny, L.; Punyadeera, C. Circulating tumour cell PD-L1 test for head and neck cancers. Oral Oncol. 2017, 75, 6-7. [CrossRef]

33. Chikamatsu, K.; Tada, H.; Takahashi, H.; Kuwabara-Yokobori, Y.; Ishii, H.; Ida, S.; Shino, M. Expression of immune-regulatory molecules in circulating tumor cells derived from patients with head and neck squamous cell carcinoma. Oral Oncol. 2019, 89, 34-39. [CrossRef]

34. Thierry, A.R.; El Messaoudi, S.; Gahan, P.B.; Anker, P.; Stroun, M. Origins, structures, and functions of circulating DNA in oncology. Cancer Metastasis Rev. 2016, 35, 347-376. [CrossRef]

35. Jahr, S.; Hentze, H.; Englisch, S.; Hardt, D.; Fackelmayer, F.O.; Hesch, R.D.; Knippers, R. DNA fragments in the blood plasma of cancer patients: Quantitations and evidence for their origin from apoptotic and necrotic cells. Cancer Res. 2001, 61, 1659-1665. [PubMed]

36. Diehl, F.; Schmidt, K.; Choti, M.A.; Romans, K.E.; Goodman, S.N.; Li, M.; Thornton, K.; Agrawal, N.; Sokoll, L.J.; Szabo, S.A.; et al. Circulating mutant DNA to assess tumor dynamics. Nat. Med. 2008, 14, 985-990. [CrossRef] [PubMed]

37. Holdhoff, M.; Schmidt, K.; Donehower, R.; Diaz, L.A. Analysis of Circulating Tumor DNA to Confirm Somatic KRAS Mutations. J. Natl. Cancer Inst. 2009, 101, 1284-1285. [CrossRef] [PubMed]

38. Han, X.; Wang, J.; Sun, Y. Circulating Tumor DNA as Biomarkers for Cancer Detection. Genom. Proteom. Bioinform. 2017, 15, 59-72. [CrossRef] [PubMed]

39. Liu, Q.; Sommer, S.S. Pyrophosphorolysis-Activated Polymerization (PAP): Application to Allele-Specific Amplification. Biotechniques 2000, 29, 1072-1083. [CrossRef]

40. Diaz, L.A.; Bardelli, A. Liquid Biopsies: Genotyping Circulating Tumor DNA. J. Clin. Oncol. 2014, 32, 579-586. [CrossRef]

41. Leary, R.J.; Sausen, M.; Kinde, I.; Papadopoulos, N.; Carpten, J.D.; Craig, D.; O'Shaughnessy, J.; Kinzler, K.W.; Parmigiani, G.; Vogelstein, B.; et al. Detection of Chromosomal Alterations in the Circulation of Cancer Patients with Whole-Genome Sequencing. Sci. Transl. Med. 2012, 4, 162ra154. [CrossRef] [PubMed]

42. van Ginkel, J.H.; Huibers, M.M.; van Es, R.J.; de Bree, R.; Willems, S.M. Droplet digital PCR for detection and quantification of circulating tumor DNA in plasma of head and neck cancer patients. BMC Cancer 2017, 17, 428. [CrossRef]

43. Mes, S.W.; Brink, A.; Sistermans, E.A.; Straver, R.; Oudejans, C.B.; Poell, J.B.; Leemans, C.R.; Brakenhoff, R.H. Comprehensive multiparameter genetic analysis improves circulating tumor DNA detection in head and neck cancer patients. Oral Oncol. 2020, 109, 104852. [CrossRef] [PubMed]

44. Wang, Y.; Springer, S.; Mulvey, C.L.; Silliman, N.; Schaefer, J.; Sausen, M.; James, N.; Rettig, E.M.; Guo, T.; Pickering, C.R.; et al. Detection of somatic mutations and HPV in the saliva and plasma of patients with head and neck squamous cell carcinomas. Sci. Transl. Med. 2015, 7, 293ra104. [CrossRef] [PubMed]

45. Schwaederle, M.; Chattopadhyay, R.; Kato, S.; Fanta, P.T.; Banks, K.C.; Choi, I.S.; Piccioni, D.E.; Ikeda, S.; Talasaz, A.; Lanman, R.B.; et al. Genomic Alterations in Circulating Tumor DNA from Diverse Cancer Patients Identified by Next-Generation Sequencing. Cancer Res. 2017, 77, 5419-5427. [CrossRef] [PubMed]

46. Palmirotta, R.; Lovero, D.; Cafforio, P.; Felici, C.; Mannavola, F.; Pellè, E.; Quaresmini, D.; Tucci, M.; Silvestris, F. Liquid biopsy of cancer: A multimodal diagnostic tool in clinical oncology. Ther. Adv. Med. Oncol. 2018, 10. [CrossRef] [PubMed]

47. Mazurek, A.M.; Rutkowski, T.; Fiszer-Kierzkowska, A.; Małusecka, E.; Składowski, K. Assessment of the total cfDNA and HPV16/18 detection in plasma samples of head and neck squamous cell carcinoma patients. Oral Oncol. 2016, 54, 36-41. [CrossRef]

48. Bettegowda, C.; Sausen, M.; Leary, R.J.; Kinde, I.; Wang, Y.; Agrawal, N.; Bartlett, B.R.; Wang, H.; Luber, B.; Alani, R.M.; et al. Detection of Circulating Tumor DNA in Early- and Late-Stage Human Malignancies. Sci. Transl. Med. 2014, 6, 224ra24. [CrossRef]

49. Ahn, S.M.; Chan, J.Y.K.; Zhang, Z.; Wang, H.; Khan, Z.; Bishop, J.A.; Westra, W.; Koch, W.M.; Califano, J.A. Saliva and Plasma Quantitative Polymerase Chain Reaction-Based Detection and Surveillance of Human Papillomavirus-Related Head and Neck Cancer. JAMA Otolaryngol. Neck Surg. 2014, 140, 846-854. [CrossRef]

50. Chan, K.A.; Woo, J.K.; King, A.; Zee, B.C.; Lam, W.J.; Chan, S.L.; Chu, S.W.; Mak, C.; Tse, I.O.; Leung, S.Y.; et al. Analysis of Plasma Epstein-Barr Virus DNA to Screen for Nasopharyngeal Cancer. N. Engl. J. Med. 2017, 377, 513-522. [CrossRef]

51. Egyud, M.; Sridhar, P.; Devaiah, A.; Yamada, E.; Saunders, S.; Ståhlberg, A.; Filges, S.; Krzyzanowski, P.M.; Kalatskaya, I.; Jiao, W.; et al. Plasma circulating tumor DNA as a potential tool for disease monitoring in head and neck cancer. Head Neck 2019, 41, 1351-1358. [CrossRef]

52. Chera, B.S.; Kumar, S.; Shen, C.; Amdur, R.; Dagan, R.; Green, R.; Goldman, E.; Weiss, J.; Grilley-Olson, J.; Patel, S.; et al. Plasma Circulating Tumor HPV DNA for the Surveillance of Cancer Recurrence in HPV-Associated Oropharyngeal Cancer. J. Clin. Oncol. Off. J. Am. Soc. Clin. Oncol. 2020, 38, 1050-1058. [CrossRef] [PubMed] 
53. Dawson, S.-J.; Tsui, D.W.; Murtaza, M.; Biggs, H.; Rueda, O.M.; Chin, S.-F.; Dunning, M.J.; Gale, D.; Forshew, T.; Mahler-Araujo, B.; et al. Analysis of Circulating Tumor DNA to Monitor Metastatic Breast Cancer. N. Engl. J. Med. 2013, 368, 1199-1209. [CrossRef] [PubMed]

54. De Maio, G. Circulating and stool nucleic acid analysis for colorectal cancer diagnosis. World J. Gastroenterol. 2014, 20, 957-967. [CrossRef]

55. Hamana, K.; Uzawa, K.; Ogawara, K.; Shiiba, M.; Bukawa, H.; Yokoe, H.; Tanzawa, H. Monitoring of circulating tumour-associated DNA as a prognostic tool for oral squamous cell carcinoma. Br. J. Cancer 2005, 92, 2181-2184. [CrossRef] [PubMed]

56. van Ginkel, J.H.; Huibers, M.M.; Noorlag, R.; de Bree, R.; van Es, R.J.; Willems, S.M. Liquid biopsy: A future tool for posttreatment surveillance in head and neck cancer? Pathobiology 2017, 84, 115-120. [CrossRef] [PubMed]

57. Rutkowski, T.W.; Mazurek, A.M.; Śnietura, M.; Hejduk, B.; Jędrzejewska, M.; Bobek-Billewicz, B.; D'Amico, A.; Pigłowski, W.; Wygoda, A.; Składowski, K.; et al. Circulating HPV16 DNA may complement imaging assessment of early treatment efficacy in patients with HPV-positive oropharyngeal cancer. J. Transl. Med. 2020, 18, 1-10. [CrossRef]

58. Tanaka, H.; Takemoto, N.; Horie, M.; Takai, E.; Fukusumi, T.; Suzuki, M.; Eguchi, H.; Komukai, S.; Tatsumi, M.; Isohashi, F.; et al Circulating tumor HPV DNA complements PET-CT in guiding management after radiotherapy in HPV -related squamous cell carcinoma of the head and neck. Int. J. Cancer 2021, 148, 995-1005. [CrossRef] [PubMed]

59. Thakur, B.K.; Zhang, H.; Becker, A.; Matei, I.; Huang, Y.; Costa-Silva, B.; Zheng, Y.; Hoshino, A.; Brazier, H.; Xiang, J.; et al. Double-stranded DNA in exosomes: A novel biomarker in cancer detection. Cell Res. 2014, 24, 766-769. [CrossRef] [PubMed]

60. Milane, L.; Singh, A.; Mattheolabakis, G.; Suresh, M.; Amiji, M.M. Exosome mediated communication within the tumor microenvironment. J. Control. Release 2015, 219, 278-294. [CrossRef]

61. Lee, Y.; El Andaloussi, S.; Wood, M.J. Exosomes and microvesicles: Extracellular vesicles for genetic information transfer and gene therapy. Hum. Mol. Genet. 2012, 21, R125-R134. [CrossRef] [PubMed]

62. Harding, C.V.; Heuser, J.E.; Stahl, P.D. Exosomes: Looking back three decades and into the future. J. Cell Biol. 2013, $200,367-371$. [CrossRef]

63. Li, P.; Kaslan, M.; Lee, S.H.; Yao, J.; Gao, Z. Progress in Exosome Isolation Techniques. Theranostics 2017, 7, 789-804. [CrossRef]

64. Hong, C.-S.; Funk, S.; Muller, L.; Boyiadzis, M.; Whiteside, T.L. Isolation of biologically active and morphologically intact exosomes from plasma of patients with cancer. J. Extracell. Vesicles 2016, 5, 29289. [CrossRef] [PubMed]

65. D'Souza-Schorey, C.; Clancy, J.W. Tumor-derived microvesicles: Shedding light on novel microenvironment modulators and prospective cancer biomarkers. Genes Dev. 2012, 26, 1287-1299. [CrossRef]

66. Ludwig, S.; Floros, T.; Theodoraki, M.-N.; Hong, C.-S.; Jackson, E.K.; Lang, S.; Whiteside, T.L. Suppression of Lymphocyte Functions by Plasma Exosomes Correlates with Disease Activity in Patients with Head and Neck Cancer. Clin. Cancer Res. 2017, 23, 4843-4854. [CrossRef]

67. Theodoraki, M.-N.; Yerneni, S.S.; Hoffmann, T.K.; Gooding, W.E.; Whiteside, T.L. Clinical Significance of PD-L1+ Exosomes in Plasma of Head and Neck Cancer Patients. Clin. Cancer Res. 2018, 24, 896-905. [CrossRef]

68. Wang, J.; Zhou, Y.; Lu, J.; Sun, Y.; Xiao, H.; Liu, M.; Tian, L. Combined detection of serum exosomal miR-21 and HOTAIR as diagnostic and prognostic biomarkers for laryngeal squamous cell carcinoma. Med Oncol. 2014, 31, 1-8. [CrossRef]

69. Theodoraki, M.-N.; Yerneni, S.S.; Brunner, C.; Theodorakis, J.; Hoffmann, T.K.; Whiteside, T.L. Plasma-derived Exosomes Reverse Epithelial-to-Mesenchymal Transition after Photodynamic Therapy of Patients with Head and Neck Cancer. Oncoscience 2018, 5, 75-87. [CrossRef]

70. Theodoraki, M.-N.; Yerneni, S.; Gooding, W.E.; Ohr, J.; Clump, D.A.; Bauman, J.E.; Ferris, R.L.; Whiteside, T.L. Circulating exosomes measure responses to therapy in head and neck cancer patients treated with cetuximab, ipilimumab, and IMRT. OncoImmunology 2019, 8, e1593805. [CrossRef]

71. Ferris, R.L. Immunology and Immunotherapy of Head and Neck Cancer. J. Clin. Oncol. 2015, 33, 3293-3304. [CrossRef] [PubMed]

72. Hammond, S.M.; Bernstein, E.; Beach, D.; Hannon, G.J. An RNA-directed nuclease mediates post-transcriptional gene silencing in Drosophila cells. Nat. Cell Biol. 2000, 404, 293-296. [CrossRef]

73. Langevin, S.; Kuhnell, D.; Parry, T.; Biesiada, J.; Huang, S.; Wise-Draper, T.; Casper, K.; Zhang, X.; Medvedovic, M.; Kasper, S. Comprehensive microRNA-sequencing of exosomes derived from head and neck carcinoma cells in vitro reveals common secretion profiles and potential utility as salivary biomarkers. Oncotarget 2017, 8, 82459. [CrossRef] [PubMed]

74. Li, L.; Li, C.; Wang, S.; Wang, Z.; Jiang, J.; Wang, W.; Li, X.; Chen, J.; Liu, K.; Li, C.; et al. Exosomes Derived from Hypoxic Oral Squamous Cell Carcinoma Cells Deliver miR-21 to Normoxic Cells to Elicit a Prometastatic Phenotype. Cancer Res. 2016, 76, 1770-1780. [CrossRef]

75. Tanaka, Y.; Kamohara, H.; Kinoshita, K.; Kurashige, J.; Ishimoto, T.; Iwatsuki, M.; Watanabe, M.; Baba, H. Clinical impact of serum exosomal microRNA-21 as a clinical biomarker in human esophageal squamous cell carcinoma. Cancer 2012, 119, $1159-1167$. [CrossRef]

76. Mitchell, P.S.; Parkin, R.K.; Kroh, E.M.; Fritz, B.R.; Wyman, S.K.; Pogosova-Agadjanyan, E.L.; Peterson, A.; Noteboom, J.; O’Briant, K.C.; Allen, A.; et al. Circulating microRNAs as stable blood-based markers for cancer detection. Proc. Natl. Acad. Sci. USA 2008, 105, 10513-10518. [CrossRef]

77. Lu, Y.C.; Chang, J.T.C.; Huang, Y.C.; Huang, C.C.; Chen, W.H.; Lee, L.Y.; Huang, B.S.; Chen, Y.J.; Li, H.F.; Cheng, A.J. Combined determination of circulating miR-196a and miR-196b levels produces high sensitivity and specificity for early detection of oral cancer. Clin. Biochem. 2015, 48, 115-121. [CrossRef] 
78. Liu, C.J.; Kao, S.Y.; Tu, H.F.; Tsai, M.M.; Chang, K.W.; Lin, S.C. Increase of microRNA miR-31 level in plasma could be a potential marker of oral cancer. Oral Diseases 2010, 16, 360-364. [CrossRef]

79. Fayda, M.; Isin, M.; Tambas, M.; Guveli, M.; Meral, R.; Altun, M.; Sahin, D.; Ozkan, G.; Sanli, Y.; Gezer, U. Do circulating long non-coding RNAs (lncRNAs)(LincRNA-p21, GAS 5, HOTAIR) predict the treatment response in patients with head and neck cancer treated with chemoradiotherapy? Tumor Biol. 2016, 37, 3969-3978. [CrossRef]

80. Shahid, N.; Iqbal, A.; Siddiqui, A.J.; Shoaib, M.; Musharraf, S.G. Plasma metabolite profiling and chemometric analyses of tobacco snuff dippers and patients with oral cancer: Relationship between metabolic signatures. Head Neck 2018, 41, 291-300. [CrossRef] [PubMed]

81. Yin, M.-Z.; Tan, S.; Li, X.; Hou, Y.; Cao, G.; Li, K.; Kou, J.; Lou, G. Identification of phosphatidylcholine and lysophosphatidylcholine as novel biomarkers for cervical cancers in a prospective cohort study. Tumor Biol. 2015, 37, 5485-5492. [CrossRef]

82. Xu, J.; Chen, Y.; Zhang, R.; Song, Y.; Cao, J.; Bi, N.; Wang, J.; He, J.; Bai, J.; Abliz, Z.; et al. Global and targeted metabolomics of esophageal squamous cell carcinoma discovers potential diagnostic and therapeutic biomarkers. Mol. Cell. Proteom. 2013, 12, 1306-1318. [CrossRef]

83. Wojakowska, A.; Zebrowska, A.; Skowronek, A.; Rutkowski, T.; Polanski, K.; Widlak, P.; Marczak, L.; Pietrowska, M. Metabolic Profiles of Whole Serum and Serum-Derived Exosomes Are Different in Head and Neck Cancer Patients Treated by Radiotherapy. J. Pers. Med. 2020, 10, 229. [CrossRef]

84. Best, M.G.; Sol, N.; Kooi, I.E.; Tannous, J.; Westerman, B.A.; Rustenburg, F.; Schellen, P.; Verschueren, H.; Post, E.; Koster, J.; et al. RNA-Seq of Tumor-Educated Platelets Enables Blood-Based Pan-Cancer, Multiclass, and Molecular Pathway Cancer Diagnostics. Cancer Cell 2015, 28, 666-676. [CrossRef] [PubMed]

85. Verlingue, L.; Alt, M.; Kamal, M.; Sablin, M.-P.; Zoubir, M.; Bousetta, N.; Pierga, J.-Y.; Servant, N.; Paoletti, X.; Le Tourneau, C. Challenges for the implementation of high-throughput testing and liquid biopsies in personalized medicine cancer trials. Pers. Med. 2014, 11, 545-558. [CrossRef]

86. Alix-Panabières, C.; Pantel, K. Clinical Applications of Circulating Tumor Cells and Circulating Tumor DNA as Liquid Biopsy. Cancer Discov. 2016, 6, 479-491. [CrossRef] [PubMed]

87. Chae, Y.K.; Oh, M.S. Detection of Minimal Residual Disease Using ctDNA in Lung Cancer: Current Evidence and Future Directions. J. Thorac. Oncol. 2019, 14, 16-24. [CrossRef] [PubMed] 